\title{
Health and sustainability in post-pandemic economic policies
}

\begin{abstract}
Governments are deciding on measures to help economies recover from the impacts of the COVID-19 pandemic, but, as in previous crises, a narrow focus on fighting the recession could have adverse effects on the environment and health. We suggest that health and sustainability should be at the heart of the economic response.
\end{abstract}

\section{Carla Guerriero, Andy Haines and Marco Pagano}

T he current COVID-19 pandemic is having devastating effects on health and on livelihoods worldwide, albeit with wide variation between countries in incidence and death rates ${ }^{1}$. At the same time, the physical distancing measures required to save millions of lives have triggered the most severe global recession on record since the Great Depression, which started in 1929 and lasted for most of the 1930s. US employee dismissals might reach 47 million, translating into a $32.1 \%$ unemployment rate in the second quarter of $2020^{1}$. According to the International Labour Organization, currently over one billion workers worldwide are at high risk of a pay cut or losing their job. Gross domestic product (GDP) growth in 2020 is expected to decline by $6 \%$ globally, $10.8 \%$ in the United States and $13 \%$ in the Eurozone ${ }^{2,3}$ (Fig. 1).

The current reduction in economic activity cannot be expected to produce long-lasting environmental benefits. Experience of the previous global financial crises suggests that any declines in greenhouse gas (GHG) emissions are likely to be short-lived and followed by an emission rebound, boosted by stimulus packages and low oil prices ${ }^{4}$. Following the 2008 recession, the subsequent growth in $\mathrm{CO}_{2}$ emissions exceeded the transient drop observed, and about $40 \%$ of the rebound effect was due to a small number of emerging economies, especially China and India. But the effect was also substantial in the European Union $(\mathrm{EU})^{4}$.

There is potential, however, to guide the huge injection of public resources into the economy required for the post-crisis recovery, to achieve employment, health, environmental and socioeconomic benefits.

\section{An integrated approach}

The COVID-19 outbreak has shown that the world is unprepared to react promptly to global health threats: most governments (for example, those of the United States, United Kingdom and France) delayed taking

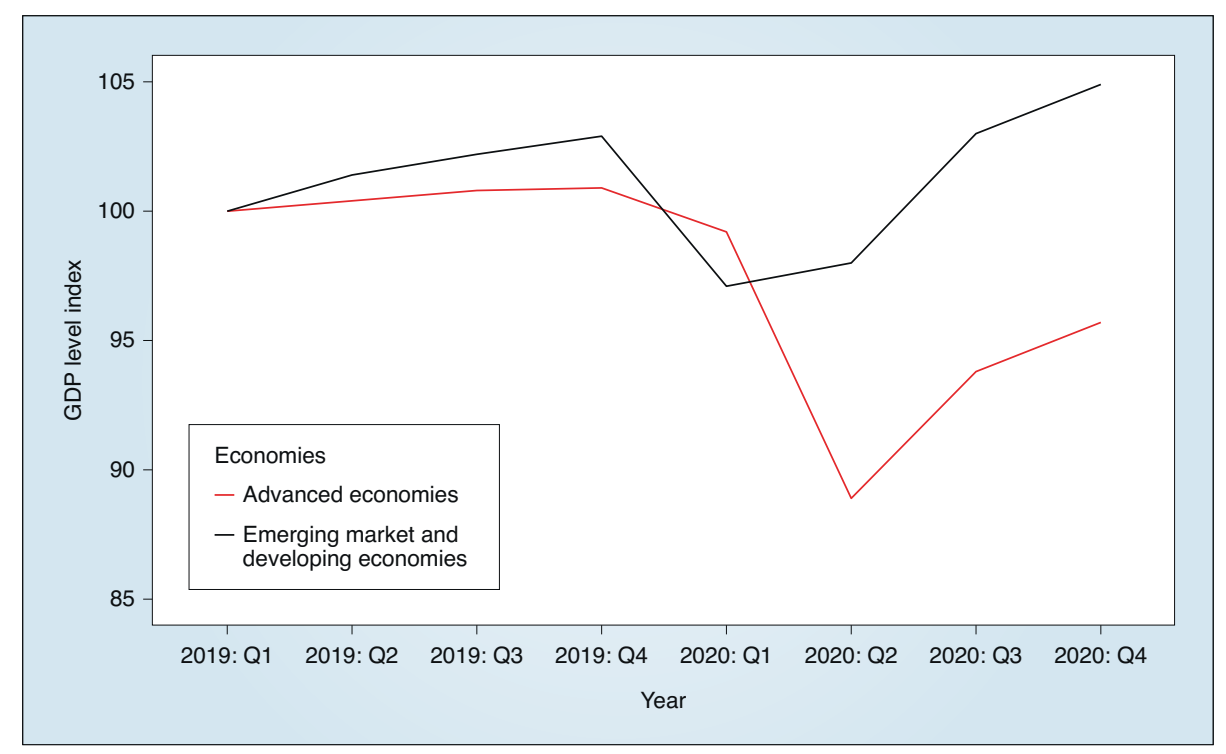

Fig. 1| Quarterly world GDP. Q1, first quarter; Q2, second quarter; Q3, third quarter; Q4, fourth quarter. Data sourced from ref. ${ }^{20}$.

action despite the devastating impacts of the virus in northern Italy, losing an important opportunity to slow transmission. This demonstrates that the typical siloed approaches of governments to risk management fail to address a global crisis with cascading large-scale health, economic and social effects. This unpreparedness does not only apply to the management of pandemics but also to the prevention of the irreversible consequences of climate change. Indeed, climate change has been described by the World Health Organization (WHO) as the greatest global threat to health in the twenty-first century ${ }^{5}$. Many of the sources of GHG emissions also emit air pollutants that raise the risks of heart disease, chronic respiratory disease, stroke and other conditions that also increase the risk of death from COVID- $19^{6}$. Ambient air pollution from burning fossil fuels is responsible alone for about 3.6 million premature deaths annually ${ }^{7,8}$.
Since there is considerable uncertainty regarding the development of an affordable vaccine to fight the virus, it is essential to improve the resilience of our society both to COVID-19 and to longer-term environmental challenges. This can be done not only by focusing on cost-effective public health interventions, but also by reinforcing health and environmental monitoring and surveillance systems and supporting international collaborative research efforts ${ }^{9}$. More generally, embedding the environment-health interface in the design of policies to tackle the post-COVID-19 recession would deliver considerable near-term benefits and strengthen society's resilience to shocks over time.

\section{Implementing an integrated economic response \\ The imperative is to place health and sustainability at the heart of the economy, implementing post-COVID-19 policies}


that achieve multiple goals - health, environmental sustainability, employment and equitable socioeconomic recovery. The policies pursued in the wake of the 20082009 and 2011-2012 financial crises failed to achieve these integrated objectives, because policy makers focused mainly on priorities like employment and growth in isolation ${ }^{4}$.

The economic policy response to the COVID-19 shock should pursue integrated actions to improve health and reduce GHG emissions by (1) removing subsidies that are harmful for health and climate and helping renewables to remain economically competitive, particularly when oil prices are low; (2) recapitalizing companies not only according to economic criteria, but also on the basis of environmental and health criteria.

The need for a post-COVID economic stimulus is an opportunity to redirect harmful subsidies from fossil fuels and other damaging products and services to more productive and necessary goods and sustainable energy. At present fossil fuel subsidies remain high in some countries and exceed subsidies for renewables ${ }^{10}$. According to the International Monetary Fund, in 2015 global post-tax fossil fuel subsidies were estimated at US\$4.7 trillion, particularly reflecting failure to account for air pollution and climate change impacts ${ }^{11}$. Setting prices at fully efficient levels would have lowered global $\mathrm{CO}_{2}$ emissions by an estimated $28 \%$ and fossil fuel air pollution deaths by $46 \%{ }^{12}$. As in previous economic crises, however, the drop in oil prices together with growing unemployment may seriously compromise efforts to decarbonize the economy ${ }^{4}$. Emerging evidence suggests that, because of their political influence and the numbers of jobs at stake, a wide range of sectors including aviation, oil and automotive industry, have successfully obtained environmentally damaging bailouts and a substantial relaxation of environmental regulation (for example, Norway has delayed oil gas industry taxes) ${ }^{13}$. Investments in renewable energy projects experienced dramatic cuts during the previous financial crises but, despite the current fall in the price of oil and the lower demand for energy, returns on investments in renewable energy compare favourably with those from fossil fuels ${ }^{14}$. They can provide a greater economic boost, leading to longer-lasting recover $y^{13}$.

Halting environmental exemptions and rollbacks and shifting subsidies from unsustainable and inefficient industries to supporting rapid decarbonization, for example by retrofitting buildings to reduce energy use, building cycling infrastructure or funding renewable energy, is an immediate priority and would be cost-effective from a health, environmental and economic perspective.

An additional complementary economic policy response to COVID-19 is to recapitalize firms so as to restart investment and growth in the economy. So far, the short-term economic response to fight the COVID-19 recession has been liquidity provision via debt financing to firms and households whose cash flow has dropped or disappeared altogether. This is clearly an urgent need because firms and families will go bankrupt otherwise. However, the injection of liquidity does not solve the possible emergence of insolvency, as the losses borne by firms during the crisis burn part of their equity capital (that is, the value of their assets minus their debts). Paradoxically, liquidity provision may aggravate the solvency problem if firms emerge from the crisis with greater, possibly crippling, indebtedness and lower equity capital, and therefore with higher risk of bankruptcy. This will eventually slow down investment and growth, as previously happened in the Eurozone in the wake of the 2008-2012 financial crises ${ }^{15}$. To avoid a repetition of that experience, the economic policy response to COVID-19 should include the injection of fresh equity capital into firms. Given households' severe wealth loss, such recapitalization will require substantial public funding, and it is essential to establish criteria to identify which firms should benefit from recapitalization with taxpayers' money. These criteria should not only include firms' economic viability, but also their environmental and health effects. Clearly, firms whose products jeopardize public health and environmental sustainability and whose business models would not be competitive if they paid the economic costs of their environmental and health externalities should not be prioritized for support.

In the EU, this can happen not only at the level of individual governments but also via a cooperative pan-European arrangement to enable firms to be recapitalized irrespective of the fiscal capacity of their national governments, that is, only on the basis of their economic potential and their contribution to a healthy environment. This would be consistent with the European Green Deal that aims to accelerate progress towards a zero-carbon economy, with major benefits for health and the environment ${ }^{16}$. The EU could establish an equity fund to recapitalize companies across Europe, financed by the European Investment Bank (EIB) with participation from long-term investors, as well as with the issuance of long-term bonds. Being directed to this broad class of investments, such a fund would be quite different in scale and scope from existing EU initiatives, such as the European Investment Fund, which focuses on funding small and medium enterprises.

On the economic front, this new fund would target firms with good profitability and growth prospects, prioritizing those that have received little (or no) state aid from their own governments; in addition, it would require funded companies to refrain from paying dividends in the near term, or repurchasing their own shares and to ensure that the capital injection is not squandered on compensation of shareholders or top managers. But beside these economic efficiency criteria, the fund should also consider health and sustainability criteria in the choice of firms to be recapitalized. By prioritizing these criteria, this fund is likely to attract institutional investors that rely on Environmental and Social (ES) ratings to allocate their investments. ES ratings are already widely used in asset management: mutual funds actively compete for climate-conscious investment flows, so as to achieve the 'Low Carbon Designation' created by Morningstar in $2018^{17}$. Moreover, stocks with high ES ratings have turned out to be particularly resilient during the COVID-19 crisis, featuring considerably higher returns than other stocks ${ }^{18}$. ES ratings would be usefully complemented by health criteria in the portfolio selection, thus also prioritizing companies producing essential diagnostic and other medical equipment, together with those whose products improve or protect health. Some investments may indeed qualify both on environmental and health criteria: for example, renewable energy technologies yield a double environmental and health benefit, with the potential to prevent about 430,000 premature deaths annually in the EU from air pollution attributable to burning fossil fuels ${ }^{8}$.

Removal of environmentally harmful subsidies and recapitalizing companies based on ES and health standards may also be an opportunity to minimize the social impacts of recession, by creating sustainable employment opportunities as part of the stimulus package. In 2018, 11 million people were employed in the renewables sector worldwide and, if pre-crisis investments are not redirected, this number could rise to 42 million jobs globally by $2050^{14}$. For instance, in the United States only, the Obama Administration's Recovery Act generated 900,000 job years of employment while driving down the costs of clean renewable energy $^{19}$. Hence, recovery from the COVID19 crisis could be a great opportunity to re-orient the economy towards sustainability while promoting employment and growth. 
In the words of President Obama's chief of staff, Rahm Emanuel: "You never want a serious crisis to go to waste." This is a very serious crisis: rather than wasting it, let us turn it into an historical opportunity.

\section{Carla Guerriero (DD $1 \times$, Andy Haines (D) 2 and Marco Pagano ${ }^{3}$}

${ }^{1}$ University of Naples Federico II, DISES, CSEF, Naples, Italy. ${ }^{2}$ Centre on Climate Change and Planetary Health, London School of Hygiene and Tropical Medicine, London, UK. ${ }^{3}$ University of Naples Federico II, CSEF, EIEF, CEPR, and ECGI, Naples, Italy.

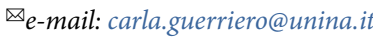

Published online: 8 June 2020

https://doi.org/10.1038/s41893-020-0563-0

References

1. COVID-19 Dashboard by the Center for Systems Science and Engineering (John Hopkins University \& Medicine, 2020); https:// coronavirus.jhu.edu/map.html
2. Faria-e-Castro, M. Back-of-the-Envelope Estimates of Next Quarter's Unemployment Rate (Federal Reserve Bank of St. Louis, 2020).

3. The UniCredit Economics Chartbook Quarterly, Macro Research (UniCredit Research, 2020); https://go.nature.com/2U0UYWK

4. Tienhaara, K. A. Environ. Policy Gov. 20, 197-208 (2010).

5. Climate Change and Human Health (WHO, 2019)

6. The OpenSAFELY Collaborative et al. OpenSAFELY: factors associated with COVID-19-related hospital death in the linked electronic health records of 17 million adult NHS patients. Preprint at medRxiv https://doi.org/10.1101/2020.05.06.20092999 (2020).

7. Prüss-Ustün, A. et al. J. Public Health (Oxf.) 39, 464-475 (2017)

8. Lelieveld, J. et al. Proc. Natl Acad. Sci. USA 116, 7192-7197 (2019).

9. Belesova, K., Haines, A., Ranganathan, J., Seddon, J. \& Wilkinson, P. Lancet 395, 96-98 (2020).

10. Renewable Power Generation Costs in 2018 (International Renewable Energy Agency, 2019).

11. Coady, D. Parry, I., Le, N. P. \& Shang, B. Global Fossil Fuel Subsidies Remain Large: An Update Based on Country-Level Estimates IMF Working Paper 19-89 (International Monetary Fund, 2019).

12. Amendment to the Temporary Framework for State aid measures to support the economy in the current COVID-19 outbreak (EU Commission, 2020).

13. Alers, M. How clean energy can power a COVID-19 recovery UNDP. United Nations Development Programme (15 May 2020).
14. Global Energy Transformation: A Roadmap to 2020 (International Renewable Energy Agency, 2018)

15. Kalemli-Ozcan, S., Laeven, L. \& Moreno, D. Debt Overhang Rollover Risk, and Corporate Investment: Evidence from the European Crisis NBER Working Paper No. 24555 (ECGI, 2020)

16. Haines, A. \& Scheelbeek, P. Lancet 395, 1327-1329 (2020).

17. Ceccarelli, M., Ramelli S. \& Wagner, A. F. Low-Carbon Mutual Funds ECGI Working Paper Series in Finance 659 (ECGI, 2020).

18. Albuquerque, R. A., Koskinen, Y., Yang, S. \& Zhang, C. Resiliency of Environmental and Social Stocks: An Analysis of the Exogenous COVID-19 Market Crash European Corporate Governance Institute - Finance Working Paper No. 676/2020 (European Corporate Governance Institute, 2020).

19. A Retrospective Assessment of Clean Energy Investments in the Recovery Act (The White House, 2016); https://go.nature. com/3dlOM3i

20. World Economic Outlook (International Monetary Fund, 2020).

Author contributions

C.G. conceived the idea and discussed it with A.H. and M.P. All authors contributed equally to the Comment.

Competing interests

The authors declare no competing interests. 